\title{
SELECTIVE ELECTROEXTRACTION OF BASE METALS FROM LEACHING SOLUTIONS OBTAINED DURING THE RECYCLING OF WASTE PRINTED CIRCUIT BOARDS. I. INTENSIVE GALVANOSTATIC ELECTRODEPOSITION OF COPPER
}

\author{
MARIAN-IOSIF FRÎNCUa, ENIKO COVACI, \\ SORIN-AUREL DORNEANU ${ }^{\mathrm{a}, \mathrm{b},{ }^{*}, \text { PETRU ILEA }}{ }^{\mathrm{a}, \mathrm{b}}$
}

\begin{abstract}
This article presents our results concerning the feasibility of selective electroextraction of copper from leaching solutions obtained during base metals recycling from waste printed circuit boards. The researches were focused on the intensive copper electrodeposition as a potential parallel paired process for the electrochemical regeneration of the leaching solutions. Preliminary tests, performed by cyclic voltammetry on 316 stainless steel disc electrode in synthetic solutions of $\mathrm{CuBr}_{2}, \mathrm{SnBr}_{2}$ and $\mathrm{PbBr}_{2}$, indicate the possibility of selective electroextraction of $\mathrm{Cu}$ if the electrodeposition potentials of $\mathrm{Sn}$ and $\mathrm{Pb}$ are not exceeded. Therefore, selective and intensive $\mathrm{Cu}$ electrodeposition tests were accomplished in galvanostatic mode, in a real sample of leaching solution, using also 316 stainless steel sheets cathodes. The experimental results demonstrate that the selective electrodeposition of $\mathrm{Cu}$ is possible in a wide range of current densities, between 200 and $600 \mathrm{~A} / \mathrm{m}^{2}$, if the concentration of $\mathrm{Cu}$ in solution of at least $12 \mathrm{~g} / \mathrm{L}$ is maintained. Under these conditions, the purity of the obtained $\mathrm{Cu}$ deposits can attain $99.6 \%$.
\end{abstract}

Keywords: waste printed circuit boards, selective electroextraction, copper recovery, electrochemical parallel paired processes

\section{INTRODUCTION}

As a result of the rapid growth of the world economy and improvement of living standards, the production rate of waste electrical and electronic equipment (WEEE) strongly increases [1], becoming two to three times higher

a Babeş-Bolyai University, Faculty of Chemistry and Chemical Engineering, Department of Chemical Engineering, 11 Arany Janos Street, Cluj-Napoca, RO-400028, Romania

${ }^{b}$ Babeş-Bolyai University, Interdisciplinary Research Institute on Bio Nano Sciences, 42 Treboniu Laurian Street, Cluj-Napoca, RO-400271, Romania

*Corresponding author: dorneanu@chem.ubbcluj.ro 
than for other urban wastes [2]. In the past two decades, WEEE has become a worldwide major pollution problem [3] with estimated quantities of about 50 million tons in 2020 [4] and over 52.2 million tons in 2021 [5]. The global shift towards sustainable resource management and the continuous depletion of high-quality virgin ore resources increase the need to develop strategies for the cyclical use of metals found in WEEE, as well as for the safe disposal of residues after recovery of the desired materials $[6,7]$. The recycling of WEEE also represents a strategy to avoid environmental pollution, although landfilling is still a notorious way of disposing this solid waste in emerging countries [8]. The WEEE recycling process also offers a valuable source of raw materials for the electronics industry [9].

The printed circuit boards (PCBs) are the most used items in almost all electronic devices [10] and/or represent their core component [11]. Usually, PCBs contain thin layers of precious metals over the metal contacts [12], significant amounts of $\mathrm{Cu}[13]$, but also traces of highly toxic ones, like $\mathrm{Pb}$ and $\mathrm{Cd}[14]$.

Currently, various technologies have been developed for the metals recycling from waste printed circuit boards (WPCBs), such as physicalmechanical, pyrometallurgical, hydrometallurgical, bioleaching methods or combinations of these approaches [15]. The hydrometallurgical methods present many advantages over the pyrometallurgical ones, including lower energy consumption, reduced capital costs and low toxic gas emissions [16]. However, conventionally, hydrometallurgical processes consume large amounts of chemicals and generate large volumes of waste waters [17]. As an alternative to the traditional PCBs recycling methods mentioned before, the electrochemical recovery of metals from WPCBs gains more and more attention, due to the high environmental compatibility [18], high energy and economic efficiency [19], minimal involvement of auxiliary materials [20] and better recovery of valuable materials [21].

Starting from the very promising results of our previous researches [21-23], the present work aimed to check the feasibility of the copper selective electroextraction from the extremely complex solutions obtained during the recovery of base metals from WPCBs using the $\mathrm{KBr} / \mathrm{HBr} / \mathrm{Br}_{2}$ leaching system. The studies were focused on the possibility to use the intensive (high rate) copper electrodeposition as a potential parallel paired process for the electrochemical regeneration of the leaching solutions which will be performed, obviously, in a divided reactor [21], simultaneously with the obtention of pure and easy valorisable $\mathrm{Cu}$ deposits. Before the galvanostatic experiments concerning the intensive $\mathrm{Cu}$ electrodeposition from the real leaching solution, preliminary tests were accomplished by cyclic voltammetry (CV) on a 316 stainless steel (SS) disc electrode in synthetic mono-component solutions of $\mathrm{CuBr}_{2}, \mathrm{SnBr}_{2}$ 
and $\mathrm{PbBr}_{2}$. CV results indicate that $\mathrm{Cu}$ can be electroextracted selectively if the electrodeposition potentials of $\mathrm{Sn}$ and $\mathrm{Pb}$ are not exceeded. Finally, the $\mathrm{Cu}$ deposits obtained by galvanostatic electrolysis were cleaned, dried, detached from the 316 SS sheet cathodes, mineralized with aqua-regia, and analysed by ICP-OES. The obtained results demonstrate that valuable and high purity Cu deposits (up to $99.6 \%$ ) can be obtained using current densities between 200 and $600 \mathrm{~A} / \mathrm{m}^{2}$ and maintaining the Cu concentration in solution higher that $12 \mathrm{~g} / \mathrm{L}$.

\section{RESULTS AND DISCUSSION}

The results of the preliminary tests performed by CV on the 316 SS disc electrode of $3 \mathrm{~mm}$ diameter, in synthetic mono-component solutions of $\mathrm{CuBr}_{2}, \mathrm{SnBr}_{2}$ and $\mathrm{PbBr}_{2}$, are presented in Figure 1.
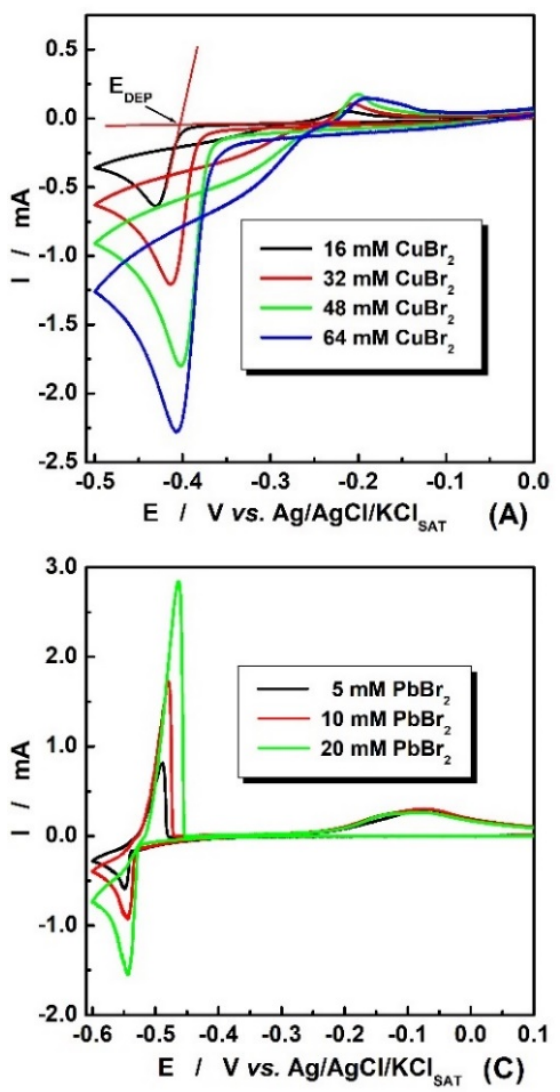

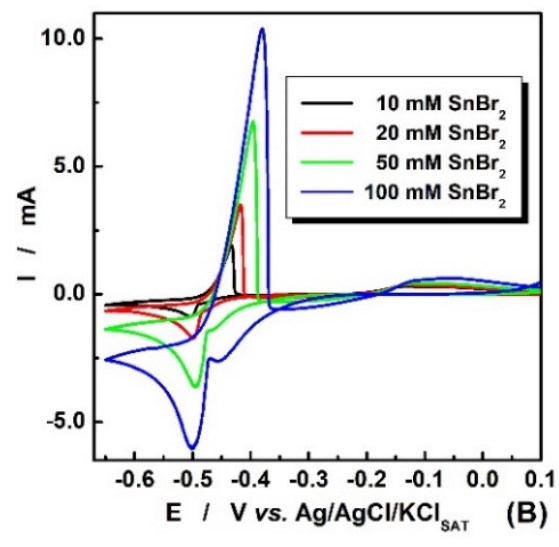

Figure 1. Voltammograms recorded by CV on 316 SS disc electrode in synthetic mono-component solutions containing $2 \mathrm{M} \mathrm{KBr}+0.5 \mathrm{M} \mathrm{HBr}+\mathrm{CuBr}_{2}(\mathrm{~A}), \mathrm{SnBr}_{2}(\mathrm{~B})$ and $\mathrm{PbBr}_{2}(\mathrm{C})$ of different concentrations (see inset) 
It is worth to note that the CV applied to study the process of metals electrodeposition/electrodissolution offers less accurate quantitative data, the peaks amplitude and position being strongly influenced by many factor like deposit morphology, electrode-deposit compatibility, vertex potential, etc. However, the CV remains a powerful tool for qualitative comparisons. Consequently, for a rigorous estimation of the $\mathrm{Cu}, \mathrm{Sn}$ and $\mathrm{Pb}$ electrochemical behaviours, we decided to evaluate the electrodeposition potential, $E_{D E P}$, where the process start effectively. As exemplified in Figure 1.C, $E_{D E P}$ corresponds to the intersection of the linear extrapolations associated with the $\mathrm{Cu}^{2+}$ to $\mathrm{Cu}^{+}$ reduction process and the effective electrodeposition process. The evaluated $E_{\text {DEP }}$ values are presented in Table 1.

Table 1. Evolution of EDEP corresponding to the $\mathrm{Cu}^{2+}, \mathrm{Sn}^{2+}$ and $\mathrm{Pb}^{2+}$ ions electrodeposition on 316 SS electrode from solutions containing different concentrations of $\mathrm{CuBr}_{2}, \mathrm{SnBr}_{2}$ and $\mathrm{PbBr}_{2}$.

\begin{tabular}{|c|c|c|c|c|c|}
\hline \multicolumn{2}{|c|}{$\mathrm{Cu}$} & \multicolumn{2}{|c|}{ Sn } & \multicolumn{2}{|c|}{$\mathbf{P b}$} \\
\hline $\begin{array}{c}{\left[\mathrm{CuBr}_{2}\right]} \\
(\mathrm{mM})\end{array}$ & $\begin{array}{c}\text { EDEP } \\
\text { (V/Ref.) }\end{array}$ & $\begin{array}{c}{\left[\mathrm{SnBr}_{2}\right]} \\
(\mathrm{mM})\end{array}$ & $\begin{array}{c}\text { EdEP } \\
\text { (V/Ref.) }\end{array}$ & $\begin{array}{c}{\left[\mathrm{PbBr}_{2}\right]} \\
(\mathrm{mM})\end{array}$ & $\begin{array}{c}\text { EDEP } \\
\text { (V/Ref.) }\end{array}$ \\
\hline 16 & -0.407 & 10 & -0.491 & 5 & -0.541 \\
\hline 32 & -0.383 & 20 & -0.485 & 10 & -0.532 \\
\hline 48 & -0.366 & 50 & -0.476 & 20 & -0.526 \\
\hline 64 & -0.355 & 100 & -0.472 & - & - \\
\hline
\end{tabular}

As it can be seen from Figure 1 and Table 1, for all three studied ions, the modification of concentration values induces only minor changes of $E_{D E P}$ in good agreement with the Nernst equation. Moreover, for the worst scenario, corresponding to the minimal $\mathrm{Cu}^{2+}$ concentration $(16 \mathrm{mM} \cong 1 \mathrm{~g} / \mathrm{L})$ and maximal concentration of $\mathrm{Sn}^{2+}(0.1 \mathrm{M} \cong 10 \mathrm{~g} / \mathrm{L})$, substantial $\mathrm{E}_{\mathrm{DEP}}$ gap, of $\sim 70 \mathrm{mV}$, occurs for $\mathrm{Cu}$ and $\mathrm{Sn}$. Similarly, for the highest $\mathrm{Pb}$ concentration $(20 \mathrm{mM} \cong 4 \mathrm{~g} / \mathrm{L})$, the $E_{D E P}$ gap increase at $\sim 120 \mathrm{mV}$. Considering these $E_{D E P}$ gaps values and that, usually, the concentration of $\mathrm{Cu}, \mathrm{Sn}$ and $\mathrm{Pb}$ ions in the spent leaching solutions vary between 300 and $600 \mathrm{mM}, 50$ and $90 \mathrm{mM}$, and 0.2 and $40 \mathrm{mM}$ [23], respectively, we concluded that the selective electroextraction of $\mathrm{Cu}$ can be performed successfully on 316 SS electrodes if the operational parameters are rigorously controlled.

As stated before, the selective $\mathrm{Cu}$ electrodeposition tests from real leaching solutions were performed in galvanostatic mode, at current values ( $I_{W E}$ ) imposed through the working electrode (WE) between -0.08 and $-0.4 \mathrm{~A}$, corresponding to current densities (i $\mathrm{WE}_{\mathrm{WE}}$ ) between 200 and $1000 \mathrm{~A} / \mathrm{m}^{2}$. Practically, using the experimental parameters indicated in Table 2, five distinct experiments were performed for similar quantities $(Q)$ of electric charge (excepting the last 
test), the corresponding $\mathrm{Cu}$ deposits being coded as D1 $\div$ D5. In addition, in Table 2 are also presented the most important parameters evaluated from the experimental data: the current efficiency $\left(\mathrm{C}_{\mathrm{EF}}\right)$, the specific energy consumption $\left(W_{S}\right)$, the average values of the WE potential ( $\left.E_{W E}, M\right)$ and of the oxidation/ reduction potential $\left(\mathrm{ORP}_{\mathrm{M}}\right)$. $\mathrm{C}_{\mathrm{EF}}, \mathrm{W}_{\mathrm{S}}, \mathrm{E}_{\mathrm{WE}, \mathrm{M}}$. and $\mathrm{ORP}_{\mathrm{M}}$ were evaluated using the main electrical parameters recorded during the experiments, presented in Figure 2, where $\mathrm{E}_{\mathrm{WE}}, \mathrm{U}_{\mathrm{T}}, \mathrm{E}_{\mathrm{CE}}, \mathrm{pH}$ and $\mathrm{ORP}$ represent the instant values of the WE potential, voltage at the terminals of the electrochemical cell, the counter electrode (CE) potential, $\mathrm{pH}$ and of the oxidation/reduction potential, respectively.

Table 2. The experimental parameters for the selective electrodeposition of $\mathrm{Cu}$ from a real leaching solution and the main evaluated parameters

\begin{tabular}{|c|c|c|c|c|c|c|c|c|}
\hline Deposit & $\begin{array}{c}\text { IWE } \\
(\mathbf{A})\end{array}$ & $\begin{array}{c}\mathbf{t} \\
(\mathbf{m i n})\end{array}$ & $\begin{array}{c}\text { iWE } \\
\mathbf{A} / \mathbf{m}^{\mathbf{2}}\end{array}$ & $\begin{array}{c}\mathbf{Q} \\
\left(\mathbf{A}^{*} \mathbf{h}\right)\end{array}$ & $\begin{array}{c}\mathbf{C}_{\mathrm{EF}} \\
\mathbf{( \% )}\end{array}$ & $\begin{array}{c}\mathbf{W} \mathbf{s} \\
(\mathbf{k W h} / \mathbf{k g})\end{array}$ & $\begin{array}{c}\text { EWE, } \\
\text { V/Ref }\end{array}$ & $\begin{array}{c}\text { ORPM } \\
\text { V/Ref }\end{array}$ \\
\hline D1 & -0.40 & 127 & 1000 & 0.847 & 50.5 & 0.389 & -0.363 & 0.047 \\
\hline D2 & -0.32 & 158 & 800 & 0.843 & 54.6 & 0.292 & -0.346 & 0.031 \\
\hline D3 & -0.24 & 211 & 600 & 0.844 & 92.8 & 0.133 & -0.343 & 0.020 \\
\hline D4 & -0.16 & 316 & 400 & 0.843 & 90.8 & 0.105 & -0.311 & 0.018 \\
\hline D5 & -0.08 & 316 & 200 & 0.421 & 89.0 & 0.086 & -0.287 & 0.032 \\
\hline
\end{tabular}

As can it be seen in Table 2, the current efficiency varies between 50.5 and $92.8 \%$, considering that the $\mathrm{Cu}$ electrodeposition process occurs predominantly mono-electronic, described by the reaction:

$$
\mathrm{CuBr}_{2}{ }^{-}+\mathrm{e}^{-} \rightarrow \mathrm{Cu}^{0}+2 \mathrm{Br}
$$

Unfortunately, in parallel with this main process, a series of secondary processes take place, described by the reactions:

$$
\begin{aligned}
& \mathrm{Cu}^{2+}+2 \mathrm{e}^{-} \rightarrow \mathrm{Cu}^{0} \\
& \mathrm{Cu}^{2+}+\mathrm{e}^{-} \rightarrow \mathrm{Cu}^{+}
\end{aligned}
$$

The intensity of the processes described by the equations (2) and (3) depends on the $\mathrm{Cu}^{2+}$ ion concentration and, especially, on the ratio between the $\mathrm{Cu}^{2+}$ and $\mathrm{Cu}^{+}$ion concentrations, which significantly influence the solution specific ORP value. From another point of view, it is important to note that, during the break between experiments and, especially, during them (when the solution is stirred), the $\mathrm{Cu}^{+}$ions are permanently oxidized to the $\mathrm{Cu}^{2+}$ ions due to the presence of atmospheric oxygen, according to the reaction:

$$
4 \mathrm{Cu}^{+}+\mathrm{O}_{2}+4 \mathrm{H}^{+} \rightarrow 4 \mathrm{Cu}^{2+}+2 \mathrm{H}_{2} \mathrm{O}
$$


This parasitic process is confirmed by the evolution of ORP throughout all experiments, which starts permanently, as illustrated in Figure 2, from a high value, and then decreases as $\mathrm{Cu}^{2+}$ ions get reduced to $\mathrm{Cu}^{+}$. The presence of the atmospheric oxygen has a negative effect on the $\mathrm{Cu}$ electrodeposition process, increasing $\mathrm{Cu}^{2+}$ concentration and favouring the secondary processes described by equations (2) and (3).

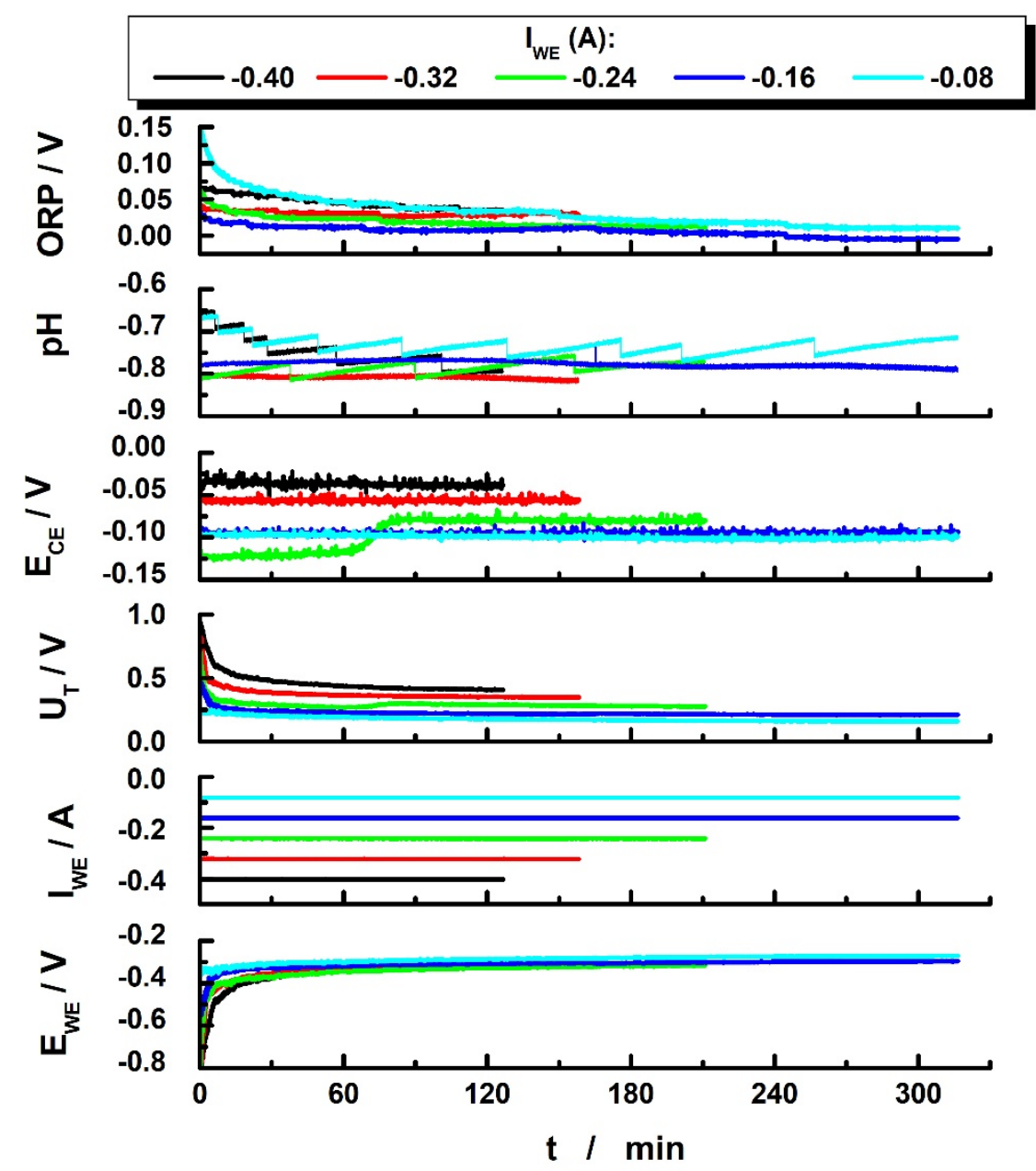

Figure 2. Evolution of the main electrical parameters during the experiments concerning the galvanostatic electrodeposition of $\mathrm{Cu}$ from the leaching solution 
SELECTIVE ELECTROEXTRACTION OF BASE METALS FROM LEACHING SOLUTIONS OBTAINED DURING THE RECYCLING OF WASTE PRINTED CIRCUIT BOARDS

Inherently, as illustrated in Figure 3, the applied current density has a significant effect on the morphology, structure and appearance of the obtained deposits.

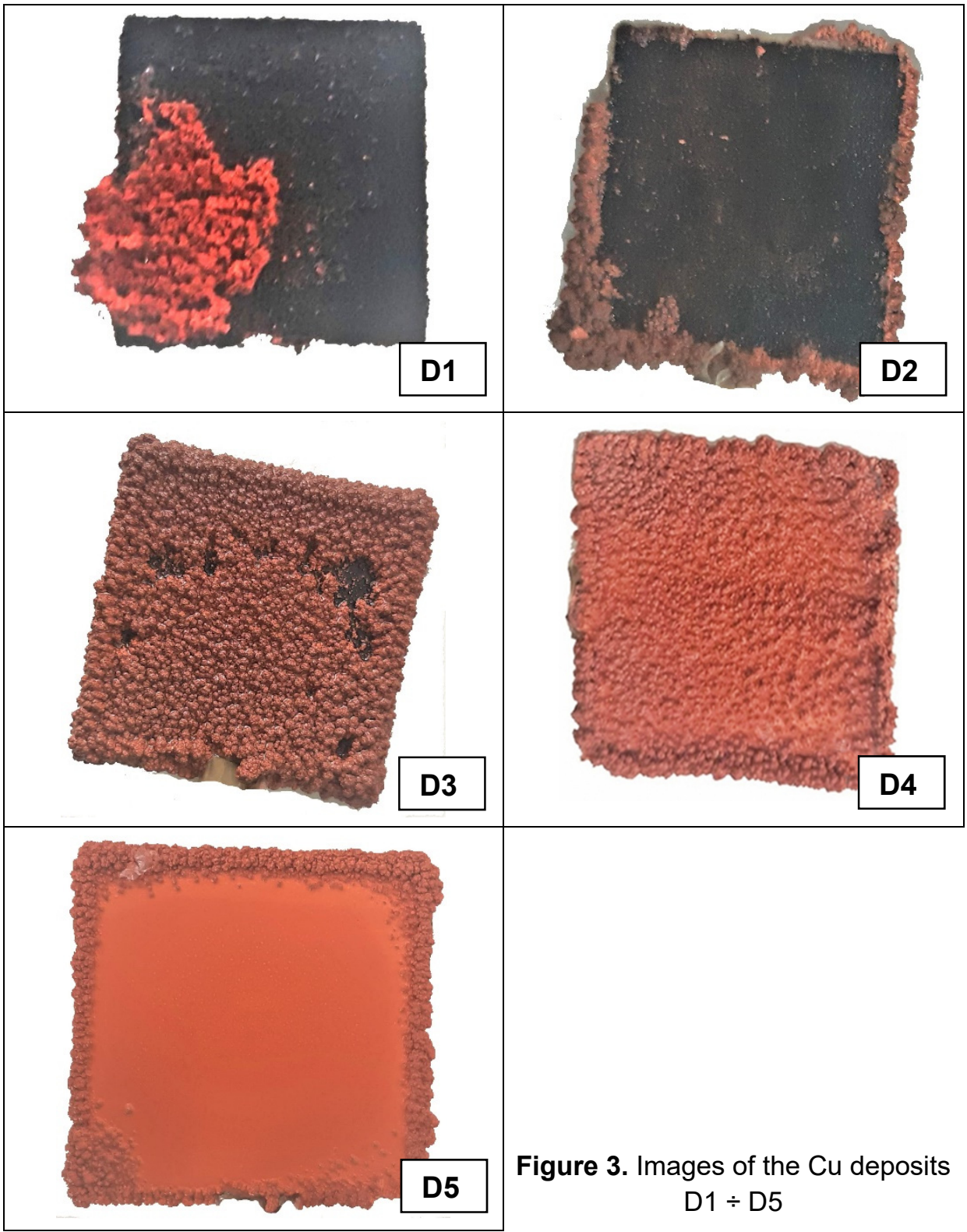


For an iWE of $1000 \mathrm{~A} / \mathrm{m}^{2}$, the lowest $C_{E F}$ and the highest $W_{S}$ values were evaluated, simultaneously with the highest values for $\mathrm{E}_{\mathrm{WE}, \mathrm{M}}$ and $\mathrm{ORP}_{\mathrm{M}}$, indicating clearly that the secondary processes (2) and (3) predominate during the experiment. Additionally, the resulting D1 covers only a small part of the cathode and has an accentuated dendritic structure, which induces high risk of detachment from the electrode surface.

For an i $\mathrm{iWE}_{\mathrm{WE}}$ of $800 \mathrm{~A} / \mathrm{m}^{2}$, the values of $\mathrm{C}_{\mathrm{EF}}, \mathrm{W}_{\mathrm{S}}, \mathrm{E}_{\mathrm{WE}}, \mathrm{M}$ and $\mathrm{ORP}_{\mathrm{M}}$ improve to a small extent, indicating a reduction in the ratio between $\mathrm{Cu}^{2+}$ and $\mathrm{Cu}^{+}$ion concentrations. In these conditions, it can be stated that the secondary processes (2) and (3) still predominate during the experiment. However, the aspect of the resulting D2 changes from an accentuated dendritic structure to a granular one. Also, in this case, D2 covers only a small part of the cathode.

At the i iWE of $600 \mathrm{~A} / \mathrm{m}^{2}$, the best value for $C_{E F}(\sim 93 \%)$, a much lower value for $W_{S},(0.133 \mathrm{kWh} / \mathrm{kg})$ and acceptable values for $E_{W E, M}$ and $O_{R P}$ were obtained, indicating that, in this case, the predominant process becomes the mono-electronic electrodeposition of $\mathrm{Cu}$. Under these conditions, D3 covers most of the cathode and has a predominantly granular structure, with a much-diminished edge effect.

For an $\mathrm{i}_{\mathrm{WE}}$ of $400 \mathrm{~A} / \mathrm{m}^{2}$, the obtained results in terms of $\mathrm{W}_{S}, \mathrm{E}_{\mathrm{WE}} \mathrm{M}$ and $\mathrm{ORP}_{\mathrm{M}}$ are improved in comparison with $\mathrm{D} 3$. Unfortunately, the $\mathrm{C}_{\mathrm{EF}}$ value presents a small decrease, suggesting that the rates of parasitic processes start to increase. In these conditions, D4 covers almost entirely the cathode surface and has a finer granular structure, but with a more evident edge effect than D3.

Finally, to avoid excessive experiment duration (more than $10.5 \mathrm{~h}$ ), we decided to halve the $Q$ value used for the $i_{W E}$ of $200 \mathrm{~A} / \mathrm{m}^{2}$. In these conditions, the best value for $W_{S}(0.086 \mathrm{kWh} / \mathrm{kg})$ and an acceptable value for $\mathrm{C}_{\mathrm{EF}}(89 \%)$ were obtained. This fact indicates that, although, in this case, the mono-electronic electrodeposition of $\mathrm{Cu}$ is the predominant process, the oxidation process with atmospheric oxygen is accentuated. As it can be seen in Figure 3, D5 completely covers the cathode with a smooth and compact film, but it has an accentuated edge effect.

In addition to the information concerning the $\mathrm{C}_{\mathrm{EF}}, \mathrm{W}_{\mathrm{S}}, \mathrm{E}_{\mathrm{WE}}, \mathrm{M}$ and $\mathrm{ORP} \mathrm{P}_{\mathrm{M}}$, and those related to the deposits appearance, the establishment of optimal operating conditions must also take into account the purity of the obtained deposits. In this respect, the deposits were subjected to mineralization in aqua regia, and the concentrations of the metallic impurities were evaluated by ICP-OES. The results obtained from these analyses are summarized in Table 3 and represent the percentage concentration (w/w) relative to the mass of the deposits. 
SELECTIVE ELECTROEXTRACTION OF BASE METALS FROM LEACHING SOLUTIONS OBTAINED DURING THE RECYCLING OF WASTE PRINTED CIRCUIT BOARDS

Table 3. Cu content and the percentage of the metallic impurities from the $\mathrm{Cu}$ deposits obtained by selective electrodeposition from real leaching solutions

\begin{tabular}{|c|c|c|c|c|c|c|c|}
\hline Deposit & Cu (\%) & Sn (\%) & Pb (\%) & Fe (\%) & Ni (\%) & Zn (\%) & Ag (\%) \\
\hline D1 & 98.93 & 0.60 & 0.10 & 0.01 & 0.02 & 0.21 & 0.10 \\
\hline D2 & 99.40 & 0.21 & 0.05 & 0.01 & 0.01 & 0.21 & 0.08 \\
\hline D3 & 99.67 & 0.09 & 0.03 & 0.00 & 0.00 & 0.15 & 0.05 \\
\hline D4 & 99.67 & 0.06 & 0.03 & 0.01 & 0.00 & 0.19 & 0.04 \\
\hline D5 & 99.68 & - & 0.04 & 0.01 & 0.00 & 0.22 & 0.04 \\
\hline
\end{tabular}

As it can be seen in Table 3, excepting the D1 case, for all other experiments, the purity of the obtained Cu deposits exceeds $99 \%$, reaching $99.68 \%$ in the case of D5. The weaker results in case of D1 are justified by the fact that, at the beginning of the experiment, EWE drops to values of -0.8 V/Ref, favouring the massive electrodeposition of impurities. Contrarily, at the lowest current density (i $\mathrm{i}_{\mathrm{WE}}=200 \mathrm{~A} / \mathrm{m}^{2}$ ), the concentration of impurities is minimal, but the electrodeposition rate becomes extremely low.

Corroborating the results presented in Figures 2 and 3 , and Tables 2 and 3 , it is obviously that the current density represents the key factor in the selective electroextraction of $\mathrm{Cu}$. Practically, the increase of the current density induces more negative $E_{W E}, M$ values, increasing the risk of the other base metals co-deposition.

Based on these observations, we suppose that an improved selective electrodeposition can be achieved using a variable profile for the current density, starting from low values in order to cover the cathode surface with a layer of compact and pure $\mathrm{Cu}$, and continuing with increasing current densities, up to $600 \mathrm{~A} / \mathrm{m}^{2}$.

\section{CONCLUSIONS}

Based on the experimental results concerning the intensive electrodeposition of $\mathrm{Cu}$ on $316 \mathrm{SS}$ electrodes from real solutions, we concluded that the selective $\mathrm{Cu}$ electroextraction can be successfully and efficiently used as the parallel paired process for the electrochemical regeneration of the leaching solutions based on the $\mathrm{KBr} / \mathrm{HBr} / \mathrm{Br}_{2}$ system. High purity $\mathrm{Cu}$ deposits, up to $99.6 \%$, can be obtained by maintaining the concentration of $\mathrm{Cu}$ ions in the leaching solution over $12 \mathrm{~g} / \mathrm{L}$ and imposing cathodic current densities between 200 and $600 \mathrm{~A} / \mathrm{m}^{2}$. 
Increased purity of the deposits and better process efficiency can be achieved by using variable current profile, avoiding oxidation of the solution with atmospheric oxygen and increasing the thickness (mass) of the deposit.

\section{EXPERIMENTAL SECTION}

\section{Chemicals}

Reagents as: $\mathrm{KBr}, \mathrm{HBr}, \mathrm{CuBr}_{2}, \mathrm{SnBr}_{2}$, and $\mathrm{PbBr}_{2}$ are purchased by Fluka and Sigma-Aldrich.

For the CV measurements, synthetic sample solutions are prepared by dissolving appropriate quantities of $\mathrm{CuBr}_{2}, \mathrm{SnBr}_{2}$, and $\mathrm{PbBr}_{2}$ in $2 \mathrm{M} \mathrm{KBr}+$ $0.5 \mathrm{M} \mathrm{HBr}$ solution.

The real leaching solution was obtained by mixing equal samples from different solutions resulted by the leaching of the exposed metals from $10 \mathrm{PC}$ motherboards in $2.2 \mathrm{~L}$ of $2 \mathrm{M} \mathrm{KBr}+0.5 \mathrm{M} \mathrm{HBr}+1 \mathrm{M} \mathrm{Br}_{2}$ solutions [22]. The ORP of the resulting mixture $(1 \mathrm{~L})$ was lowered by placing it over 2 $\mathrm{kg}$ of WPCBs, after which the solution $\mathrm{pH}$ was adjusted to 0.1 by addition of $\mathrm{HBr} 47 \%$. The concentrations of the main metallic ions in the solution were: $12 \mathrm{~g} / \mathrm{L} \mathrm{Cu} ; 6.9 \mathrm{~g} / \mathrm{L} \mathrm{Sn} ; 4.4 \mathrm{~g} / \mathrm{L} \mathrm{Pb} ; 9 \mathrm{~g} / \mathrm{L} \mathrm{Zn} ; 5.6 \mathrm{~g} / \mathrm{L} \mathrm{Fe} ; 0.8 \mathrm{~g} / \mathrm{L} \mathrm{Ni}$.

\section{Experimental methods}

Cyclic voltammetry was performed using a computer-controlled multichannel potentiostat (DXC240, Datronix Computer, Romania). The electrochemical glass cell $(50 \mathrm{~mL})$ was equipped with a $316 \mathrm{SS}$ disc $(\phi=3 \mathrm{~mm})$ as WE, a $\mathrm{Ag} / \mathrm{AgCl} / \mathrm{KCl}_{\text {sat }}$ as reference electrode (Ref.) and a Pt wire $(\phi=0.5 \mathrm{~mm}, \mathrm{~L}=10$ $\mathrm{cm})$ as CE. All the CV measurements were performed using a scan rate of $50 \mathrm{mV} / \mathrm{s}$.

In order to preserve the electrolyte composition, the selective $\mathrm{Cu}$ electrodeposition experiments in galvanostatic mode (from real leaching solution) were performed in an undivided polypropylene electrochemical cell with a volume of $1 \mathrm{~L}$, in which $400 \mathrm{~mL}$ of previous described real leaching solution was introduced. For the same reason, a $3 \mathrm{~cm} \times 8 \mathrm{~cm}$ Cu plate with a thickness of $0.5 \mathrm{~mm}$ was used as CE (soluble anode). The cell was equipped with one $2 \mathrm{~cm} \times 2 \mathrm{~cm}$ plate WE made from $316 \mathrm{SS}$ sheet with a thickness of $0.2 \mathrm{~mm}$, the face non-exposed to the CE being insulated. WE, $\mathrm{CE}$ and 2 reference electrodes of $\mathrm{Ag} / \mathrm{AgCl} / \mathrm{KCl}_{\text {sat }}$ type were connected to a computer controlled potentiostat (DXC236, Datronix Computer, Romania). Additionally, 2 laboratory multi-meters (Consort C863, Consort, Belgium) were used as galvanically insulated electrochemical interfaces with high input 
impedance between the data acquisition board (NI6221, National Instruments, USA) and the $\mathrm{pH}$ and ORP sensors (SP10T and SO50X, respectively, both from Consort, Belgium). During the experiments, the electrolyte was stirred using a magnetic stirrer (FB 15001, Fischer Scientific). Before each test, the WE was polished using emery paper (1200 and 2000), washed with double-distilled water and dried under nitrogen jet. After each experiment, the SS electrode was removed from the electrochemical cell and the obtained $\mathrm{Cu}$ deposit was washed with $2 \mathrm{M} \mathrm{KBr}+0.5 \mathrm{M} \mathrm{HBr}$ mixture (to avoid the precipitation of $\mathrm{Cu}$, $\mathrm{Sn}$ and $\mathrm{Pb}$ ions), cleaned with double-distilled water and dried with pure acetone and pure nitrogen jet. Finally, the Cu deposits were detached from the SS cathode, weighed with an analytical balance, and mineralised with $28 \mathrm{~mL}$ of aqua-regia. The resulted solutions were analysed by ICP-OES method, using a SPECTRO CIROS CCD spectrometer (SPECTRO Analytical Instruments, Germany). The concentrations of the dissolved metallic ions from the leaching solutions were measured by flame atomic adsorption spectroscopy (FAAS), using an AVANTA-PM spectrometer (GBC, Australia).

\section{ACKNOWLEDGMENTS}

This work was supported by a grant of the Romanian Ministry of Research and Innovation, CCCDI-UEFISCDI, project number PN-III-P1-1.2-PCCDI-20170652 / 84PCCDI/2018, within PNCDI III.

\section{REFERENCES}

1. D. Zhang, Y. Cao, Y. Wang, G. Ding, Resour. Conserv. Recycl., 2020, 152, 1-7.

2. S. Akbari, A. Ahmad, Chem. Eng. Process., 2019, 142, 1-8.

3. Q. Tan, Q. Dong, L. Liu, Q. Song, Y. Liang, J. Li, J. Clean. Prod., 2017, 148, 509-517.

4. R. Wang, Z. Zhu, S. Tan, J. Guo, Z. Xu, J.Hazard. Mater., 2020, 385, 1-10.

5. H. Rau, A.R. Bisnar, J.P. Velasco, Sustainability, 2020, 12(10), 4037, 1-21.

6. Z. Wu, W. Yuan, J. Li, X. Wang, L. Liu, J. Wang, Front. Environ. Sci. Eng., 2017, $11,8-21$.

7. H. Wang, M. Han, S. Yang, Y. Chen, Q. Liu, S. Ke, Environ. Int., 2011, 37, 80-85.

8. R.Z. Rebello, M.T.W.D. Carneiro Lima, L.H. Yamane, R.R. Siman, Resour. Conserv. Recycl., 2020, 153, 1-7.

9. S. Ghosh, Thin Solid Films, 2019, 669, 641-658.

10. R.S. El-Nasr, S.M. Abdelbasir, A.H. Kamel, S.S.M. Hassan, Sep. Purif. Technol., 2020, 230, 1-11. 
11. X.N. Zhu, C.C. Nie, H. Zhang, X.J. Lyu, J. Qiu, L. Li, J. Clean. Prod., 2020, 248:119235, 1-8.

12. R.A. Mesquita, R.A.F. Silva, D. Majuste, Process. Saf. Environ. Prot., 2018, 120, 107-117.

13. T. Moyo, B.H Chirume, J. Petersen, Resour. Conserv. Recycl., 2020, 152, 1-7.

14. L. Leyssens, B. Vinck, C.V. Straeten, F. Wuyts, L Maes, Toxicology, 2017, 387, 43-56.

15. J. Hao, Y. Wang, Y. Wu, F. Guo, Resour. Conserv. Recycl., 2020, 157, 104787, $1-15$.

16. A. Tuncuk, V. Stazi, A. Akcil, E.Y. Yazici, H. Deveci, Miner. Eng., 2012, 25, $28-$ 37.

17. H. Li, J. Eksteen, E. Oraby, Resour. Conserv. Recycl., 2018, 139, 122-139.

18. S. Fogarasi, F. Imre-Lucaci, A. Egedy, Á. Imre-Lucaci, P. Ilea, J. Waste Manag., 2015, 40, 136-143.

19. L.A. Diaz, T.E. Lister, J. Waste Manag., 2018, 74, 384-392.

20. C. Cocchiara, S.A. Dorneanu, R. Inguanta, C. Sunseri, P. Ilea, J. Clean. Prod., 2019, 230, 170-179.

21. S.A. Dorneanu, Studia UBB Chemia, 2017, LXII(3), 177-186.

22. S.A. Dorneanu, A.A. Avram, A.H. Marincaş, N. Cotolan, T. Frenţiu, P. Ilea, Studia UBB Chemia, 2018, LXIII(4), 147-158.

23. S.A. Dorneanu, E. Covaci, F. Imre-Lucaci, G. L. Turdean, Studia UBB Chemia, 2019, LXIV(2), Tom II, 555-565. 